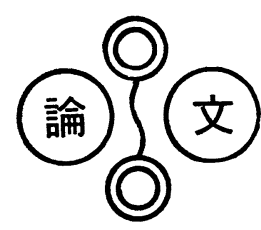

各種石炭チャーの二酸化炭素による ガス化の活性評価ならびに スチームによるガス化との比較

-1982. 12. 8 受理一

岡山大学 笠岡 成光, 阪田 祐作, 童 楚良*

\section{1. 緒言}

石炭のガス化は，石炭の熱分解とこれによって生成 するチャーのガス化の 2 つの過程からなりたってい る。石炭の熱分解速度はチャーのガス化速度に比べ て，いちじるしく大きく，かつガス化剤ガスの組成よ りは周囲温度や昇温速度などの熱的な条件の影響を大 きくらける。したがって，石炭のガス化速度を支配す る因子はチャーのガス化速度を支配する因子であると いえる。

さきに著者ら は燃料比が1.2から7.9の範囲にある 19種の石炭から同じ条件で調製したチャーについて, 熱重量法による基礎的なガス化実験をスチーム $\left[\mathrm{H}_{2} \mathrm{O}\right.$

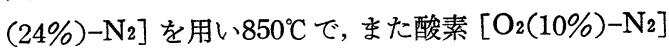

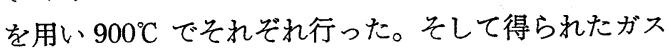
化率 $\mathrm{f}$ 対ガス化時間 $\theta$ の関係をそのシグモイド性（ガ ス化速度 $\mathrm{df} / \mathrm{d} \theta$ 曲線で, 反応途中で速度に最大值を示 す）の有無に関係なく, 精度よく表示する修正体積反 応モデルによる速度式， $\mathrm{f}=1-\exp \left(-\mathrm{a} \theta^{\mathrm{b}}\right)$ を提出する とともにチャーのガス化活性の定量的な評価法を検討 し，ガス化活性が原料石炭の燃料比あるいは石炭や于 ヤーの H/C 原子数比と相関性を示すことなどを報告 した。

本研究では, 既報1) の19種の石炭に, さらに太平洋 炭 (日本産), Illinois \#6 炭 (米国産), 苯荘 ( $\mathrm{ZaO}-$ zhang) 炭と開灤 (Kailuan) 炭（いずれる中国産）を 加えた, 燃料比1.0〜7.9の23種の石炭について, 同じ 条件で調製したチャーの二酸化炭素 $\left[\mathrm{CO}_{2}(20 \%)-\mathrm{N}_{2}\right]$ による常圧ガス化を主として $950^{\circ} \mathrm{C}$ で行い，これらの チャーのガス化活性序列を求め, 既報1) のスチームや 酸素によるガス化の場合と同じように燃料比 3 を境い にして挙動が大きく異なることを確認した。また，代 表的な 4 種の石炭チャーについて, 二酸化炭素濃度

工学部合成化学教室 岡山市津島中3-1-1

*中国化工部化肥工業研究所
(10６0\%) やチャーの平均粒径（0.5２.0mm) およ びガス化温度 $\left(800 \sim 1,400^{\circ} \mathrm{C}\right)$ を変えた実験を行い, ガス化の速度和よび活性化エネルギーへの $\mathrm{CO}_{2}$ 濃度 とチャーの粒径の次数依存性の決定を, スチームガス 化の場合と併せて行い, 両者の結果を対比した。さら に本研究でガス化活性の評価に用いた修正体積反応モ デル式と, ガス化過程を細孔表面積の変化で記述した Random Pore モデル2) の化学反応支配式と比較し, 類似点, データの適合性, 両式によるそれぞれの $2 つ$ の定数の対応性などを検討した。これらの検討結果に ついて報告する。

\section{2. 石炭とチャー}

用いた23種の石炭銘と分析結果を総括して Table 1 に示した。元素分析は, CとHは Pregl 法で, Nは Kjeldahl 法で JIS M8813 飞準じて行い, またSは $1,000^{\circ} \mathrm{C}$ での空気燃焼による生成ガスを JIS K0103 に 準じたアルセナゾ皿を指示薬とする酡酸バリウム溶液 による滴定法で行った。残りの元素をO(酸素)とみな し Odiff で表し，それぞれ無水・無灰(dry ash free, daf と略記）基準で示した。

揮発分 $(\mathrm{VM})$, 固定炭素 $(\mathrm{FC})$ および高温燃焼灰 分 (HTA) の分析法は既報》のと招りである。また Table 1 中に LTA と略記したのは, 燃焼による化学 的変質をほとんどうけていない石炭含有鉱物量3) で酸 素プラズマ低温灰化装置（柳本製作所製，LTN 2 SN 型)による測定結果である。T。で略記したのは，石 炭 (平均粒径 $0.5 \mathrm{~mm}$ ) を $\mathrm{N} 2$ 流 $\left(300 \mathrm{Ncm}^{3} / \mathrm{min}\right)$ 中で $20^{\circ} \mathrm{C} / \mathrm{min}$ の定速昇温熱分解したさいの 全熱分解減量 の $1 \%$ 減量したときの温度で減量開始の目安となる温 度4)である。Table 1は石炭の燃料比 (=FC/VM) の 順に記しているが， T。は 190〜240 C 範囲にあり， ある種の傾向性はみられない。

な打, 以上の試料石炭の乾燥重量は $\mathrm{N}_{2}$ 流中, $110^{\circ} \mathrm{C}$ で 1 時間の処理を基準として db (dry basis) で略記 


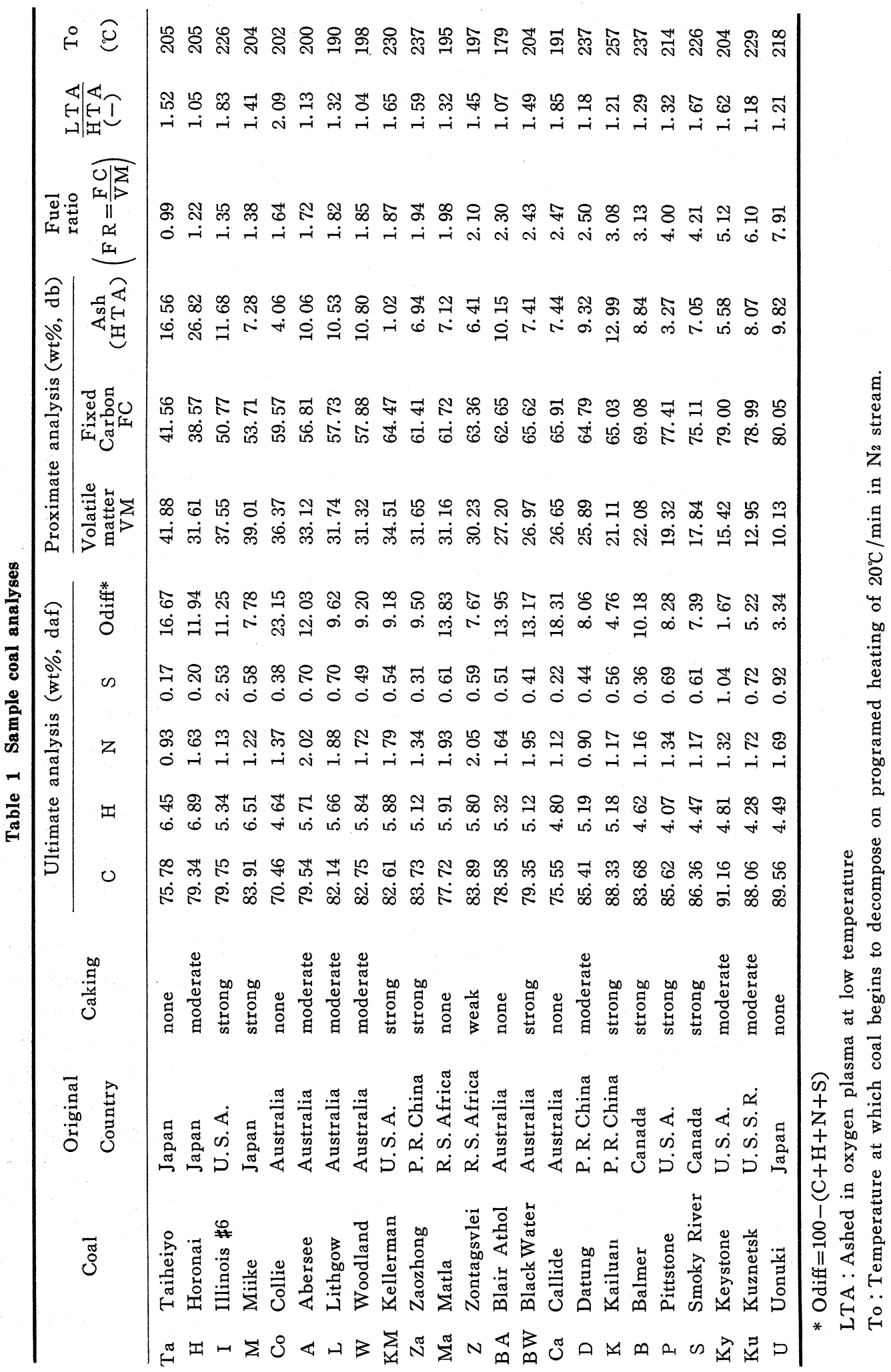


各種石炭チャーの二酸化炭素によるガス化の活性評価ならびにスチームによるガス化との比較(笠岡他) 337

した。

さて,これらの石炭を電気炉を用い $1,000^{\circ} \mathrm{C} て ゙, \mathrm{~N}_{2}$ 流 中, 7 分, 30 分および60分と時間を変えて熱分解 $($ 脱揮 発)し,節別後おるに平均粒径 $1.0 \mathrm{~mm}(-12 /+24 \times ッ シ$ ュ)のものをチャーとして実験に供した。以後のチャー の名称は Table 1 の左端に示す英字記号で略記する。

\section{3. 実験方法}

実験の装置と手法は既報5) と基本的に同じであり， スチーム供給方式のみ, 注射器による水の直接注入 (マイクロフィーダー)・加熱・蒸発の方式に改造して いる。常圧流通式微量熱天秤は $1,000^{\circ} \mathrm{C}$ 以下では透明 石英製反応管（内径 $29 \mathrm{~mm}$ ）を具元たるの（島津製作 所製 TM-2 型)，1,100〜1,400 ではアルミナ製反応 管 (内径16. $5 \mathrm{~mm}$ ) を具えたもの（島津製作所製 DT30型)を用いた。チャー（150mg）は $1,000^{\circ} \mathrm{C}$ 以下で は石英製の細い棒で製作したカゴ（内径 $20 \mathrm{~mm}$, 高さ

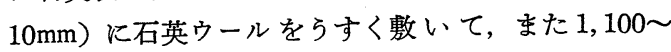
$1,400^{\circ} \mathrm{C}$ の高温では, チャー（30mg）は白金網製のカ ヨ゙ (80メッシュ, 内径 $13.5 \mathrm{~mm}$, 高さ $7 \mathrm{~mm})$ の中に, そ れぞれチャー粒子ができる限り孤立するように充媜 し, チャー粒子間吵でガスの滞留が起こらないように 注意を払った。

ガス化剤ガス組成は $\mathrm{CO}_{2}(10 \sim 60 \%)-\mathrm{N}_{2}$ 和よび $\mathrm{H}_{2} \mathrm{O}$ (16 41\%)-N2である。総流量は $500 \mathrm{Ncm}^{3} / \mathrm{min}(\mathrm{TM}$ 2 型) および $400 \mathrm{Ncm}^{3} / \mathrm{min}(\mathrm{DT}-30$ 型)で,それぞれ， ガス化速度への影響の無視できる流量域にあることを 予め確かめている。

出ロガス 組成の経時変化は, 2 基の ガスクロマトグ ラフで熱天秤によるガス化速度と同時に追測した ${ }^{155) 。 ~}$ また出ロガスを, 化学発光方式の $\mathrm{NO}_{x}$ メーター（柳 本製作所製）により生成する NO の連続測定も行っ た。さらに代表的なチャーと，そのガス化途中のチャ 一の比表面積をガスクロマトグラフ 式表面積測定装 置（島津製作所製ADS-1B型）による $\mathrm{N}_{2}$ 吸着量から Langmuir 式により求めた。

\section{4. チャーのガス化の速度式と活性評価法}

チャーの完全ガス化による重量減少量 W。(g)は, 無水・無灰 (daf) 基準の 固定炭素分に相当し, チャー の初期重量を $\omega_{0}(\mathrm{~g})$, 灰分含有率を $\alpha_{\mathrm{a}, \mathrm{o}}(\mathrm{g} / \mathrm{g}$ （チャ 一) とすると, 次式が成り立つ。

$$
\mathrm{W}_{\mathrm{o}}=\omega_{\mathrm{o}}\left(1-\alpha_{\mathrm{a}, \mathrm{o}}\right),(\mathrm{g}(\mathrm{daf}))
$$

ガス化率 $\mathrm{f} は \mathrm{~W}$ 。を基準とした重量減少率で定義し

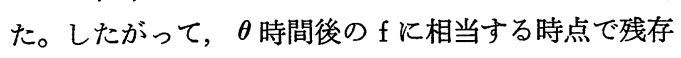
する固定炭素の重量Wは,

$$
\mathrm{W}=\mathrm{W}_{\mathrm{o}}(1-\mathrm{f}),(\mathrm{g}(\mathrm{daf}))
$$

固体・流体間反応の立場から, 重量(あるいは体積） 1)62 9) や表面積2)10111) を基準とするガス化速度式が種 々提出されており， $\mathrm{f}$ 対 $\theta$ の関係に対する工学的な意 義付けが 続けられている(1227) 9 12) 15)。たと兄ば W。 あるいはWを基準とする，ガス化速度 $\mathrm{R}_{\mathrm{f}}\left(\mathrm{g} / \mathrm{g}\left(\mathrm{W}_{\mathrm{o}}\right) \cdot\right.$ min)あるいは瞬間ガス化速度 $R i(g / g(W) \cdot \min )$ と， さらに絶対ガス化速度 $\mathrm{Rw}(\mathrm{g} / \mathrm{min})$ との間には，それ ぞれの定義から，次式の関係がある。

$$
\begin{aligned}
& \mathrm{Rw}=W o R_{\mathrm{f}}=\mathrm{WRi} \\
& \mathrm{R}_{\mathrm{f}}=\mathrm{df} / \mathrm{d} \theta=\mathrm{Ri}(1-\mathrm{f})
\end{aligned}
$$

チャーの $\mathrm{f}$ 対 $\theta$ データに対して, 以下に述べる手順 に従ってその速度の解析およびガス化活性の定量的評 価を行った。

(i ) 実測の $\mathrm{f}$ 対 $\theta$ を積分速度式, (5)式を線型化し た（6）に適用して定数 $\mathrm{a}$ とbを最小二乗法で決定す る。

$$
\begin{aligned}
& \mathrm{f}=1-\exp \left(-\mathrm{a} \theta^{\mathrm{b}}\right) \\
& \mathrm{Y}=\ln \mathrm{a}+\mathrm{bX} ; \mathrm{Y}=\ln [-\ln (1-\mathrm{f})], \\
& \mathrm{X}=\ln \theta
\end{aligned}
$$

ここで, 定数 $\mathrm{b}=1$ の場合は，（5)式から明らかな ように，体積反応モデルあるいは全域反応モデルの化 学反応支配式に相当する ${ }^{6)}$ 。定数 $\mathrm{b}$ が $0<\mathrm{b} \leq 1$ の範团 にある場合は, 定数 a の值とは関係なく, ガス化率速 度 $R_{\mathrm{f}}$ が反応開始時 $(\theta=f=0)$ 飞执いて最大であり, 以後, ガス化の進行に伴って単調に減少していく, 一

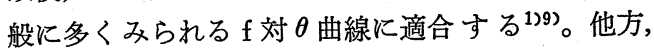
$\mathrm{b}>1$ では, $\mathrm{R}_{\mathrm{f}}$ が反応途中で最大值を示し， $\mathrm{f}$ 対 $\theta$ 曲 線がシグモイド ( $\mathrm{S}$ 字) 型曲線に適合し，(5)式は, とくに Bhatiaら ${ }^{2)}$ 速度式と異なって $\mathrm{R}_{\mathrm{f}}$ が最大值を 示す現象が $0 \leq \mathrm{f}<1$ のいかなるところで起っても精度 よく表示できることが特徵である。

(ii) 定数 $\mathrm{a}$ と b が決定されると, 瞬間ガス化速度 Ri の $\mathrm{f}$ による変化が(7)式のように得られる。

$$
\mathrm{Ri}=\mathrm{a}^{(1 / \mathrm{b})} \mathrm{b}[-\ln (1-\mathrm{f})]^{(\mathrm{b}-1) / \mathrm{b}}=\mathrm{k}(\mathrm{f})
$$

(4)式のように $\mathrm{R}_{\mathrm{f}}$ が任意の時間後にチャー中に残 留する固定炭素の量, (1-f) の 1 次に比例すると考え ると，Ri は見かけの速度定数 $\mathrm{k}(\mathrm{f})$ とみなすことがで きるので, (5)式は $\mathrm{k}(\mathrm{f})$ がガス化の進行,すなわち $\mathrm{f}$ によって変化すると考えるモデルである $[(7)$ 式 $]$ ここ の速度定数が反応期間中一定でないことは，すでに報 告されているチャーのスチームや水素によるガス化 ${ }^{16)}$ 17)，石炭の熱分解 ${ }^{18)}$ そ执いて活性化エネルギーが $\mathrm{f} に$ よって増加・減少する現象に対応するものと考允られ る。すなわち, 石炭の熱分解が単一反応ではなく, 複 数の反応が逐次的にあるいは並行して起こっていると 


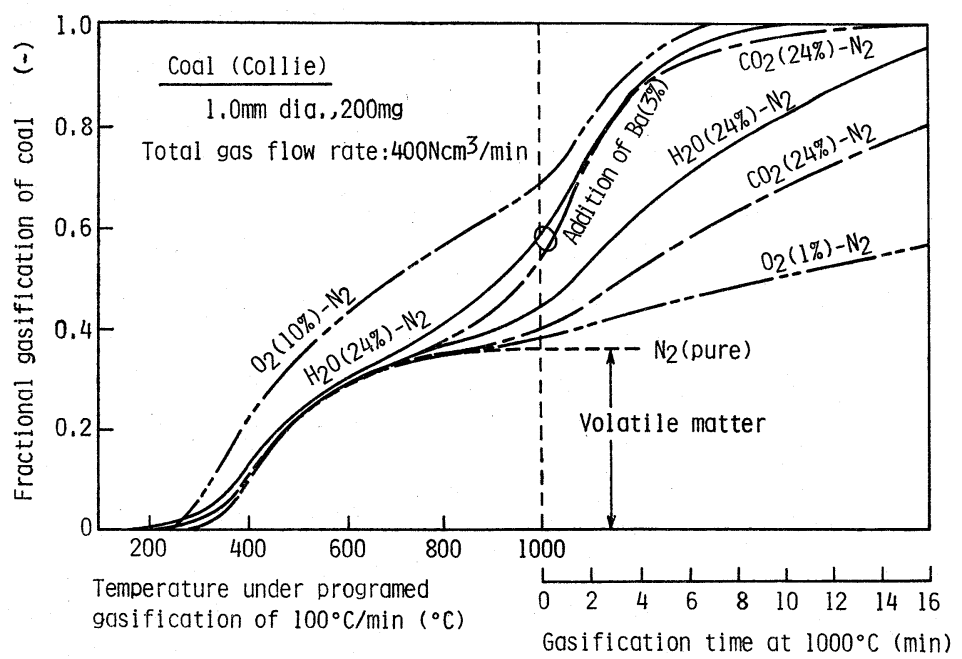

Fig. 1 Comparison of gasification rates of coal (Collie) in different atmospheres, and examples of catalytic effect of $\mathrm{Ba}(3 \%)$ compound added by impregnation method

理解する ${ }^{19320)}$ のと同様に，基本的にはチャー表面の炭 素の化学的ポテンシャルは均等ではなく, 常にガス化 されやすい炭素からガス化が進行するものと考えられ る。たとえばチャーのスチームガス化に拈いては，主 反応 $\left(\mathrm{C}+\mathrm{H}_{2} \mathrm{O} \rightarrow \mathrm{CO}+\mathrm{H}_{2}\right)$ に対して生成 $\mathrm{CO}$ の転化 反応 $\left(\mathrm{CO}+\mathrm{H}_{2} \mathrm{O} \rightarrow \mathrm{CO}_{2}+\mathrm{H}_{2}\right)$ やこの反応で生成する $\mathrm{CO}_{2}$ によるガス化 $\left(\mathrm{C}+\mathrm{CO}_{2} \rightarrow 2 \mathrm{CO}\right)$, さらに共存する $\mathrm{CO}, \mathrm{H}_{2}, \mathrm{CH}_{4}$ などによるガス化抑制効果 ${ }^{5211}$ や含有鉄 成分による接触ガス化能5)22) などが複雑に関与しあう 結果，活性化エネルギーが全ガス化過程にわたって均 等でなくなるとして理解できる。

（iii）ガス化活性を代表する指標として，平均速度定 数（代表活性） $\overline{\mathrm{k}}$ を次式で定義し算出する。

$$
\overline{\mathrm{k}}=\int_{0}^{1} \mathrm{k}(\mathrm{f}) \mathrm{df} \fallingdotseq \int_{0.01}^{0.99} \mathrm{k}(\mathrm{f}) \mathrm{df}
$$

この $\overline{\mathrm{k}}$ は (7) 式から算出される $\mathrm{f}=0.5$ に和ける速 度定数で精度よく近似することもでさる $[(9) \text { 式 }]^{11}$ 。

$$
\overline{\mathrm{k}} \fallingdotseq \mathrm{k}_{\mathrm{f}=0.5}=\mathrm{a}^{(1 / \mathrm{b})} \mathrm{b}[\ln 2]^{(\mathrm{b}-1) / \mathrm{b}}
$$

\section{5. 実験結果ならびに考察}

5.1 石炭の熱分解とチャーのガス化

Fig.1は，例として Collie 炭を純 $\mathrm{N}_{2}, \mathrm{O}_{2}(1 \%, 10 \%)$ $-\mathrm{N}_{2}, \mathrm{CO}_{2}(24 \%)-\mathrm{N}_{2}$ および $\mathrm{H}_{2} \mathrm{O}(24 \%)-\mathrm{N}_{2}$ でそれ ぞれ $110^{\circ} \mathrm{C}$ から $100^{\circ} \mathrm{C} / \mathrm{min}$ で定速昇温し, 続いて上限 温度の $1,000^{\circ} \mathrm{C}$ で定温ガス化した場合のそれぞれの重 量減少の様相を比較したものである。図のたて軸の 0 と 1 はそれぞれ石炭と灰分に相当する。2 段階で重量 減少が起こって扣り, 前半は熱分解による脱揮発チャ
一化の過程であり, 後半はチャーのガス化の過程であ る。

チャー化速度は, 高濃度 $\mathrm{O}_{2}(10 \%)$ の場合以外はガ ス化剤ガス組成が変わっても，また $\mathrm{Ba}(\mathrm{OH}) 2$ 水溶 液から $\mathrm{Ba}(3 \%)$ 化合物を含浸担持させても ${ }^{9)}$ ，純 $\mathrm{N}_{2}$ 流中での熱分解の場合とほとんど一致し，300～800 C まで昇温時間の約 5 分間でチャ一化が完了している。 Flash pyrolysis といわれる $10^{2} \sim 10^{4} \mathrm{C} / \mathrm{s}$ 程度の高速 昇温操作 $\left.{ }^{19}\right)$ に比べると，かなり打そい $100^{\circ} \mathrm{C} / \mathrm{min}$ の昇 温下でさえもこのチャー化反応は，きわめて速やかで ある。すなわら石炭表面での分解生成ガスの分圧が高

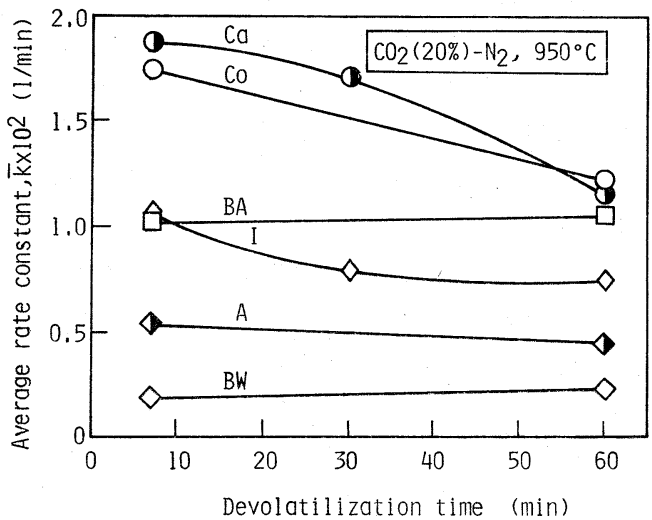

Devolatilization temperature : $1000^{\circ} \mathrm{C}$

Fig. 2 Effect of devolatilization time of parent coal on gasification rate of char with $\mathrm{CO}_{2}$ 


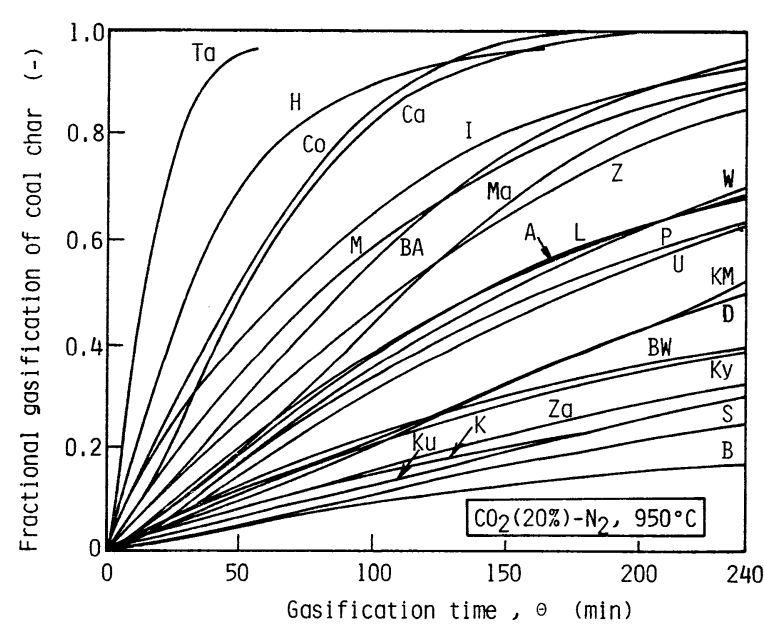

Chars : prepared by devolatilization in $\mathrm{N}_{2}$ stream for 7 minutes at $1000^{\circ} \mathrm{C}$

Fig. 3 Gasification rate of various coal chars with $\mathrm{CO}_{2}$

く，ガス化剤ガス分子が表面に到達しにくいことを示 している。ガス化剂ガスのガス化能の差異や添加触媒 の効果が明らかに認められるのは，チャーのガス化過 程であり，これが完了するには，たとえばガス化能 が $\mathrm{CO}_{2}$ よりも高い $\mathrm{H}_{2} \mathrm{O}$ による無触媒系ガス化です $1,000^{\circ} \mathrm{C}$ で約 20 分を要し, 熱分解（チャー化）に比べ てその速度はいちじるしく小さい。また， $1,000{ }^{\circ} \mathrm{C}$ 以 下の場合，一般に表面化学反応支配といわれている ${ }^{13)}$ 215)21)。熱分解 (チャー化) の速度も, 当然, 炭種によ

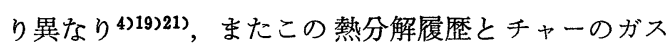
化活性の関係7)16)21) についても不明な点が多く残され ているが，本研究は既報1)にひさつついて石炭のガス 化利用上の 律速過程であるチャーの ガス化に着目し て，以下の検討を加えた。

Fig. 2 はチャーのガス化速度におよぼす原炭の熱分 解 ( $\mathrm{N}_{2}$ 流中, $\left.1,000^{\circ} \mathrm{C}\right)$ によるチャー化処理時間の影 響を代表的な石炭について，平均速度定数(代表活性) $\overline{\mathrm{k}}$ で比較したものである。用いた 6 種の石炭の然料比 は1.4〜2.5の範囲にあり, $\mathrm{I}<\mathrm{Co}<\mathrm{A}<\mathrm{BA}<\mathrm{BW}<\mathrm{Ca}$ の順に大である。粘結性は, $\mathrm{Co}, \mathrm{BA}, \mathrm{Ca}$ はきわめて

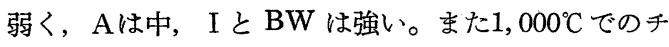
+一化時間を 7 分から60分と長くしても熱分解（脱揮 発) 減量は, ほとんど 変らず, Table 1 の工業分析值 $\left(900^{\circ} \mathrm{C}\right)$ とほぼ等しい。しかしながら，チャー化時間 を長くすると，ガス化活性が低下するもの(I, Co, Ca) もあれば,ほとんど影響をうけないもの (A, BA, BW) など様々で, 燃料比や粘結性の高低などによる影響は

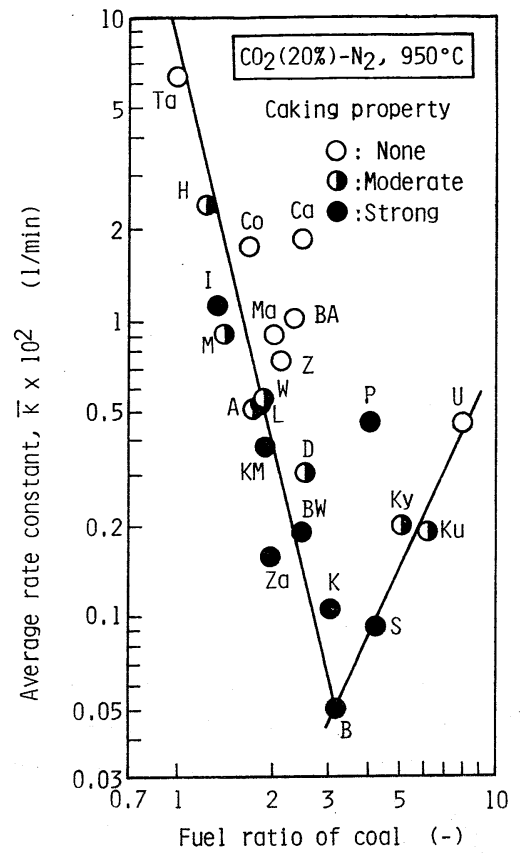

Fig. 4 Relation between average rate constant $(\overline{\mathbf{k}})$ in $\mathrm{CO}_{2}$-gasification of coal char and fuel ratio of parent coal

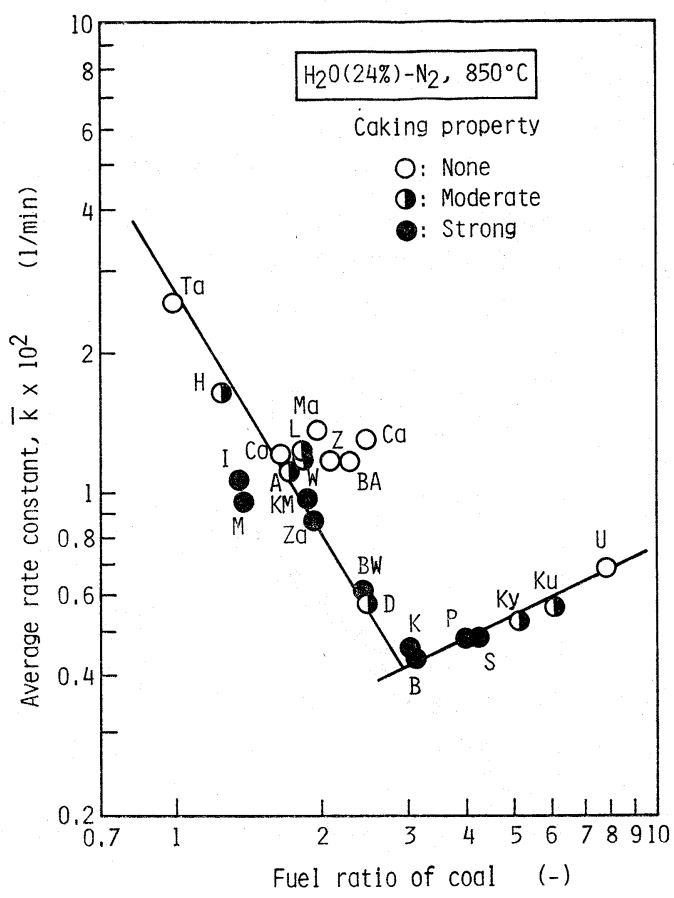

Fig. 5 Relation between average rate constant $(\overline{\mathbf{k}})$ in steam-gasification of coal char and fuel ratio of parent coal 
見いだしがたく，今後追求すべき課題のひとつであ る。以後は, $1,000^{\circ} \mathrm{C}, 7$ 分間処理によるチャーを用い た。

\section{2 各種チャーのガス化活性の比較}

Fig.3は23種の石炭を $\mathrm{N}_{2}$ 流中, $1,000^{\circ} \mathrm{C}$ で 7 分間, 熱分解処理して得たチャーの $950^{\circ} \mathrm{C}$ での $\mathrm{CO}_{2}(20 \%)$ - $\mathrm{N}_{2}$ とよる同一条件下のガス化速度曲線であり, 炭種 によりいちじるしい差異を示している。Fig.4は, Fig. 3 の曲線上の任意の点を用い, 既述の手順に従って得 た $\overline{\mathrm{k}}$, 原炭の燃料比に対して両対数点経したもので ある。Fig. 5 は, $\mathrm{N}_{2}$ 流中, $900^{\circ} \mathrm{C}$ で60分間, 熱分解処 理して得たチャーの, $850^{\circ} \mathrm{C} て ゙ の ~ \mathrm{H}_{2} \mathrm{O}(24 \%)-\mathrm{N}_{2}$ によ るガス化データリに, 本研究で追加した 4 種のチャー の結果を加兄て, Fig.4の結果と比較するために 両対 数点綴したものである。 $\mathrm{CO}_{2}$ ガス化 (Fig.4) と $\mathrm{H}_{2} \mathrm{O}$ ガス化(Fig.5), さらに $\mathrm{O}_{2}(10 \%)-\mathrm{N}_{2}$ ガス化 $\left(900^{\circ} \mathrm{C}\right)^{1)}$ の結果も含めて, ガス化活性序列の傾向はよく類似し ている。すなわち，いずれる燃料比が 3 付近でガス化 活性は最小となり，3 付近以上での変化は緩慢である が, 3 付近以下では, 然料比の減少とともに, ガス化 活性は鋭敏に増大している。さらに, 燃料比が 2 付近 のチャーについて詳しく調べると, 粘結性の小さいも のの方が活性は高く, 強粘結性炭では活性が低い傾向 が認められ，この点は既述のチャー化条件との関連性 も含めて今後, 検討を要する。

活性の最も高い太平洋炭チャー(Ta)の最も低い Balmer 炭チャー(B) 対する $\overline{\mathrm{k}}$ の比は, $\mathrm{CO}_{2}$ ガス化 で126倍, $\mathrm{H}_{2} \mathrm{O}$ ガス化で 5.9 倍であり, 各種チャーの 活性の相違は $\mathrm{CO}_{2}$ ガス化の方が, きわめていちじる しい。な拈，このようにチャーのガス化活性を支配す

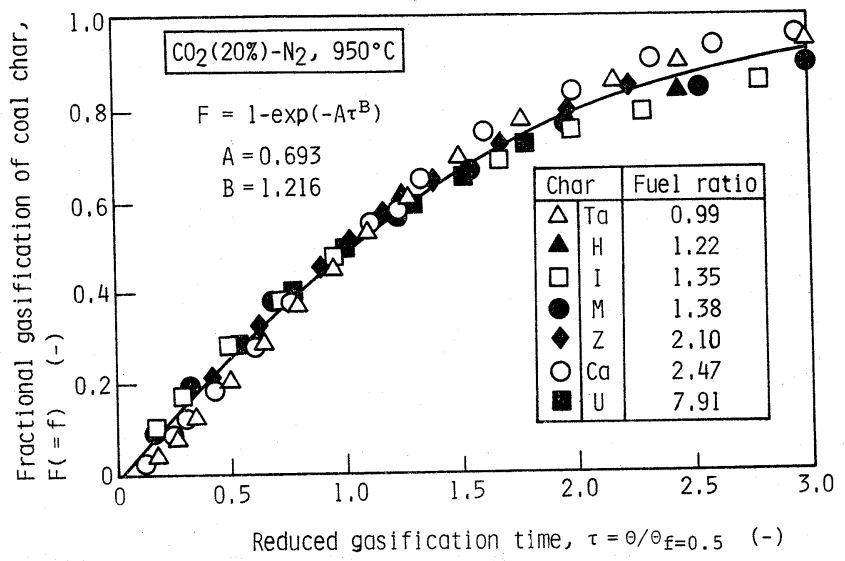

Fig. 6 Unification of gasification curves shown in Fig. 3 to correlation equation (10)
る因子の検討として, $\mathrm{H}_{2} \mathrm{O}$ ガス化と $\mathrm{O}_{2}$ ガス化に対し て比較的相関性の高かった $\mathrm{H} / \mathrm{C}$ 原子数比 ${ }^{1)}$ と $\mathrm{CO}_{2}$ ガ ス化の $\overline{\mathrm{k}}$ (Fig.4) との相関性を試みたが, 結果は既報 ${ }^{1}$ よりる芳しくなかった。これは $\mathrm{CO}_{2}$ ガス化に用いた チャーの熱分解温度が $1,0000^{\circ} \mathrm{C}$ であり, $\mathrm{H}_{2} \mathrm{O}$ や $\mathrm{O}_{2}$ ガ ス化の場合の熱分解温度 $900^{\circ} \mathrm{C}$ よりも高いことが，こ の原因のひとつではないかとも考学られる。Duttaら 11)の提案した原炭の酸素含有率 (wt $\%(\mathrm{daf}))$ も, さら に相関性は低かった。したがって, $\mathrm{CO}_{2}, \mathrm{H}_{2} \mathrm{O}, \mathrm{O}_{2}$ 飞 よるチャー（23種）のガス化活性を巨視的に知る因子 としては, 現時点では, 燃料比の大小をみるのが最む 有効で，かつ簡便と思われる。

さて, 生成ガスは本条件下の $\mathrm{CO}_{2}$ によるガス化で は, すべて $\mathrm{CO}$ であり， $\mathrm{H}_{2} \mathrm{O}$ によるガス化では既報 1)5)のと拈り, $\mathrm{H}_{2}, \mathrm{CO}, \mathrm{CO}_{2}$ と微量の $\mathrm{CH}_{4}$ であり, $\mathrm{H}_{2}$ / $\left(\mathrm{CO}+\mathrm{CO}_{2}\right)$ モル比は1.1〜1.6であった。また，いず れのガス化でもNO の生成は認められなかった。

\section{3 各種チャーのガス化速度の相関}

Fig.3に拈いて, ガス化率 $\mathrm{f}=0.5$ 飞達する所要時間 $\theta_{\mathrm{f}=0.5}$ 亿着目 ${ }^{23)}$ すると, データは割愛するが, この数 值もまた $\mathrm{H}_{2} \mathrm{O}$ ガス化や $\mathrm{O}_{2}$ ガス化の場合 ${ }^{1)}$ と同様に $\overline{\mathrm{k}}$ と一定の関係を示し, ガス化活性の定量的な指標とし て利用できる。Fig. 3 の各ガス化曲線について, ガス 化時間 $\theta$ を $\theta_{\mathrm{f}=0.5}$ で無次元化した時間 $\tau\left(=\theta / \theta_{\mathrm{f}=0.5}\right)$ で 再計算すると, 23 本の $\mathrm{f}$ 対 $\tau$ 曲線は, Fig. 6 とその代 表例を示したように，きわめて良好な近似で 1 本の曲 線にまとめられる。すなわち, 既報1 の $\mathrm{H}_{2} \mathrm{O}$ や $\mathrm{O}_{2}$ に よるガス化の場合とまったく同じで，(5)式と同一形 式の(10)式で表された。

$$
\mathrm{F}=1-\exp \left(-\mathrm{A} \tau^{\mathrm{B}}\right) ; \mathrm{A}, \mathrm{B} \text { : 定数 }
$$

本条件下の $\mathrm{CO}_{2}$ によるガス化での $\mathrm{A}$ 0.693, Bは $1.216 て ゙$, 相関保数は0.990で あった。また, この場合, B>1 であるか 5, 23本の曲線 (Fig. 3) は, 平均してシ グモイド (S字) 型を示していることにな る。な拉, $\mathrm{H}_{2} \mathrm{O}$ ガス化では $\mathrm{A}=0.675, \mathrm{~B}$ $=1.340, \mathrm{O}_{2}$ ガス化では $\mathrm{A}=0.738, \mathrm{~B}=$ 1.887 であった1)。

以上のように，いずれのガス化に执いて も炭種・炭質にほとんど無関係にひとつの 曲線（(10)式）にまとめることができるこ と, またガス化活性が燃料比と深い相関性 を示すことなどから，すべてのチャーのガ ス化が基本的には，かなりよく類似した反 応機構で進行していることが示唆される。 
各種石炭チャーの二酸化炭素によるガス化の活性評価ならびにスチームによるガス化との比較(笠岡他) 341

換言すれば，石炭中の鉱物質や灰分など無機物質の主 要ガス化反応 $\left(\mathrm{C}+\mathrm{H}_{2} \mathrm{O} \rightarrow \mathrm{CO}+\mathrm{H}_{2}, \mathrm{C}+2 \mathrm{H}_{2} \mathrm{O} \rightarrow \mathrm{CO}_{2}\right.$ $\left.+2 \mathrm{H}_{2}, \mathrm{C}+\mathrm{CO}_{2} \rightarrow 2 \mathrm{CO}, \mathrm{C}+1 / 2 \mathrm{O}_{2} \rightarrow \mathrm{CO}\right)$ 飞対する触 媒作用は, $\mathrm{CO}$ の転化反応 $\left(\mathrm{CO}+\mathrm{H}_{2} \mathrm{O} \rightarrow \mathrm{CO}_{2}+\mathrm{H}_{2}\right)$ 飞

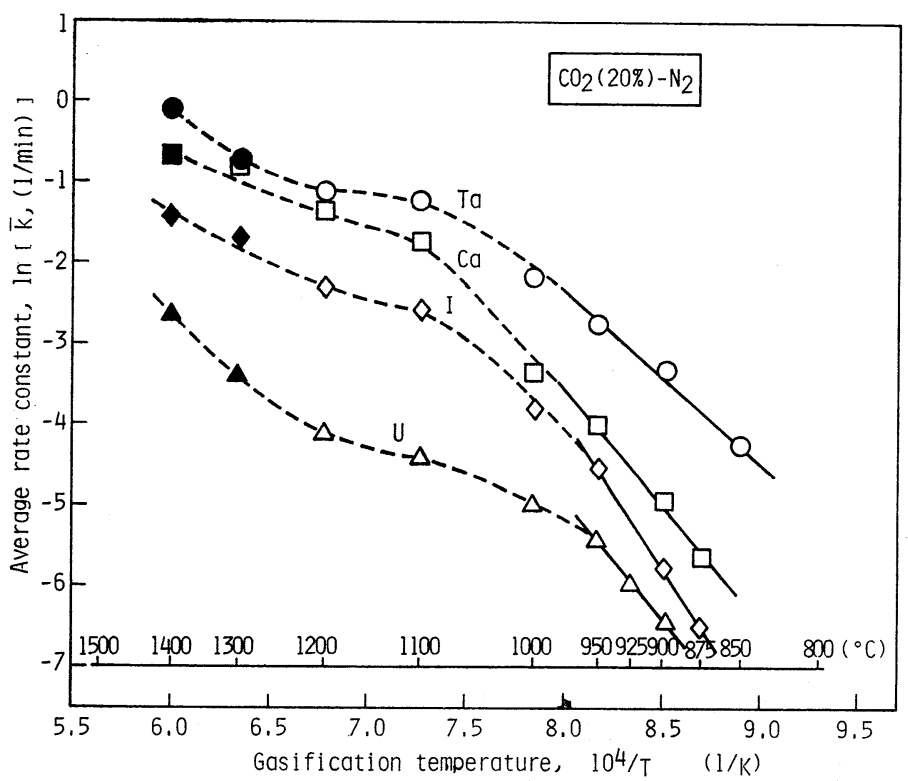

Black marks indicate that ash was melted down by gasification run

Fig. 7 Arrhenius plot of average rate constant $(\bar{k})$ in $\mathrm{CO}_{2}$-gasification of coal chars

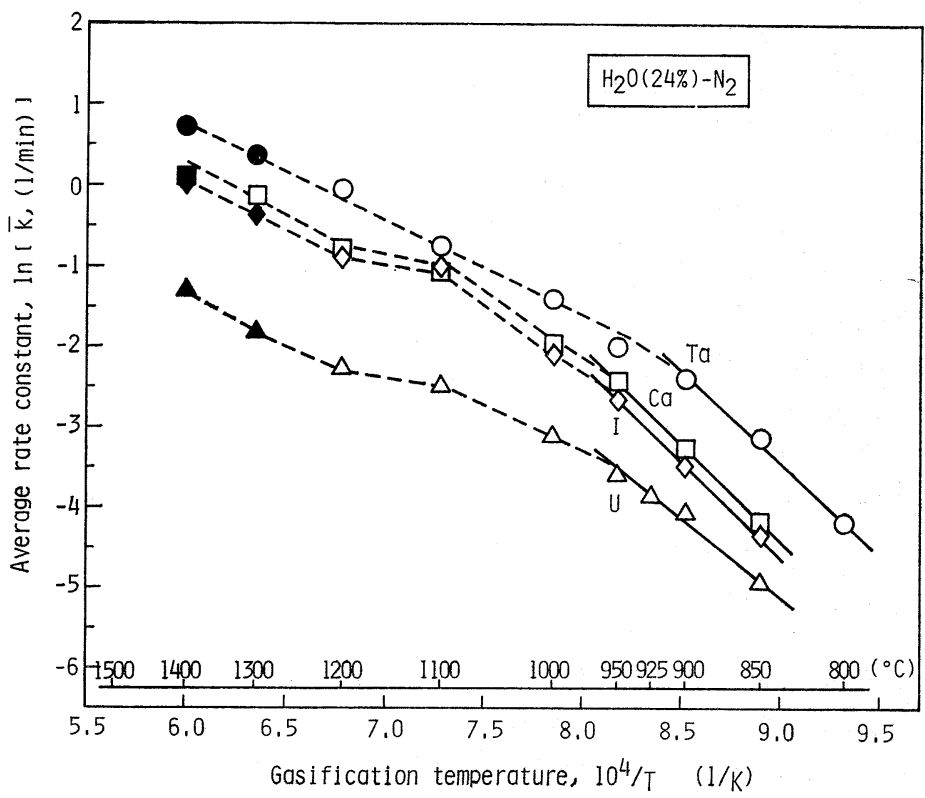

Black marks indicate that ash was melt down by gasification run

Fig. 8 Arrhenius plot of average rate constant $(\bar{k})$ in steam-gasification of coal chars
対して若干，認められる24)以外はあまり大きく期待で きない25)とい方る。しかし，石炭含有鉱物質が示す，石 炭やチャー中の $\mathrm{N} \cdot \mathrm{S}$ 化合物の $\mathrm{HCN}, \mathrm{NO}, \mathrm{NH}_{3}$, $\mathrm{H} 2 \mathrm{~S}, \mathrm{COS}$ などへのガス化変換反応に対する微妙な触

媒能については, 別途に検討を行 っている26)。

5.4 チャーのガス化速度の

解析

太平洋炭 ( $\mathrm{Ta}$, 褐炭), Illinois \#6炭 (I, 粘結性歴青炭), Callide 炭 ( $\mathrm{Ca}$, 非粘結性歴青炭) および 魚貫炭 (U, 無煙炭) の 4 種の于 ヤーを代表として選び, $\mathrm{CO}_{2}$ ガス 化と $\mathrm{H}_{2} \mathrm{O}$ ガス化に拈ける代表活 性 $\overline{\mathrm{k}}$ の，ガス化剂ガス分圧 $\mathrm{P}$ とチ 中一平均粒子径 $\mathrm{d}_{\mathrm{p}}$ へのそれぞれ の次数依存性, $\mathrm{m}$ と, 打よび活 性化エネルギーEとの関係を次式 のように沶いて検討した。 $\overline{\mathrm{k}}=\mathrm{k}_{\mathrm{o}} \mathrm{p}_{\mathrm{j}}{ }^{\mathrm{m}} \mathrm{d}_{\mathrm{p}}{ }^{\mathrm{n}} \exp (-\mathrm{E} / \mathrm{RT})$;

$\mathrm{j}: \mathrm{CO}_{2}, \mathrm{H}_{2} \mathrm{O}$

5.4 .1 活性化エネルギー

Fig. 7 と Fig. 8 は, それぞれ $\mathrm{CO}_{2}$ ガス化と $\mathrm{H}_{2} \mathrm{O}$ ガス化の 800

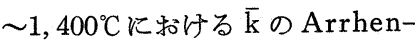
ius 点綴である。高温域での実験 後, 試料血の白金網をみると，灰 分が熔融して網目を1部，ふさい でいた。図中の黒い記号はこのこ とを示している。両図の $\overline{\mathrm{k}}$ の温度 依存性はまったく類似しており， $950^{\circ} \mathrm{C}$ 付近以下では直線性を示し ているので，活性化エネルギーを 評価することができる。 $1,000^{\circ} \mathrm{C}$ 付近以上から鉱物質・灰分が熔融 する直前の $1,200^{\circ} \mathrm{C}$ 付近までは, 一部，拡散の影響のためか, いず れのチャーでも見かけ活性化エネ ルギーは小さくなり，灰分が熔融 する高温域 $\left(1,300 \sim 1,400^{\circ} \mathrm{C}\right)$ で はふたたび活性化エネルギーが大 きくなっている。そして注目すべ き点は, $950^{\circ} \mathrm{C}$ 付近以下での 炭種 による相対的な活性の比率・序列 が $1,400^{\circ} \mathrm{C}$ の高温域までもそのま 
Table 2 Rate analyses of gasification of coal char with carbon dioxide and steam Average rate constant $: \bar{k}=k_{o} p^{m} d_{p}{ }^{n} \exp (-E / R T)$

\begin{tabular}{|c|c|c|c|c|c|c|}
\hline \multirow{2}{*}{ Parent coal } & \multicolumn{3}{|c|}{ Gasification with $\mathrm{CO}_{2}-\mathrm{N}_{2}$ mixture } & \multicolumn{3}{|c|}{ Gasification with $\mathrm{H}_{2} \mathrm{O}-\mathrm{N}_{2}$ mixture } \\
\hline & $\mathrm{m}$ & $\mathrm{n}$ & $\mathrm{E}$ & $\left.\mathrm{m}^{3}\right)$ & $\mathrm{n}$ & $\mathrm{E}$ \\
\hline Taiheiyo & $0.50^{1)}$ & 0 & 47 & 0.43 & 0 & 46 \\
\hline Illinois $\sharp 6$ & $0.54^{1)}$ & 0 & 74 & 0.43 & 0 & 47 \\
\hline Callide & $0.47^{1)}$ & - & 62 & 0.42 & - & 47 \\
\hline Uonuki & $0.45^{2)}$ & - & 58 & 0.67 & - & 38 \\
\hline
\end{tabular}

$\mathrm{P}_{\mathrm{CO}_{2}}=0.1 \sim 0.6 \mathrm{~atm}, \mathrm{P}_{\mathrm{H}_{2} \mathrm{O}}=0.16 \sim 0.41 \mathrm{~atm}$,

$\mathrm{d}_{\mathrm{p}}$ : Particle diameter $; 0.5 \sim 2 \mathrm{~mm}$,

$\mathrm{E}:$ Activation energy $(\mathrm{kcal} / \mathrm{mol})$

1) $: 950^{\circ} \mathrm{C}$, 2) $\left.: 1,000^{\circ} \mathrm{C}, 3\right): 900^{\circ} \mathrm{C}$

ま成立していることである。また，鉱物質の熔融を伴 っている $1,100^{\circ} \mathrm{C}$ 付近以上では少なくともチャーの一 部は，ガス化されるべき固定炭素部分と鉱物質とが相 分離を起こしていると推察されるから，ガス化の進行 の様子は $1,000^{\circ} \mathrm{C}$ 付近以下とは異なっていると思われ る。

Table 2 K, $1,000^{\circ} \mathrm{C}$ 以下の温度域に打ける(11)式の 結果を総括して示した。すなわち 4 種のチャーの $\mathrm{CO}_{2}$ ガス化の活性化エネルギーEは 47 74kcal/mol であ る。Dutta ら ${ }^{11}$ は本研究之同様の常圧・熱重量法に上 る $\mathrm{CO}_{2}$ ガス化を行い，Illinois \#6 炭を含む 6 種の石炭

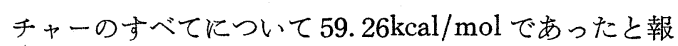
告している。また各種のグラファイト類や活性炭（原 料：ヤシガラ) などの石炭チャ一以外の炭素質の $\mathrm{CO}_{2}$ ガス化についての $\mathrm{E} は, 1,000^{\circ} \mathrm{C}$ 以下では, 本研究と 同程度の範囲にある ${ }^{8)}$ 。また Table 2 で $\mathrm{CO}_{2}$ ガス化と $\mathrm{H}_{2} \mathrm{O}$ ガス化の $\mathrm{E}$ 比較すると, $\mathrm{H}_{2} \mathrm{O}$ ガス化では炭種 間の差が小さく, 同一チャーの $\mathrm{E} は \mathrm{CO}_{2}$ ガス化の場 合の方が大きく, チャーI の場合には $30 \mathrm{kcal} / \mathrm{mol}$ の 差が認められた。たと党ば加圧流動層(最高10気圧)で のPittsburgh seam 炭のチャーについての結果 ${ }^{27)}$ は, 初速度から求めた $\mathrm{E} は, \mathrm{CO}_{2}$ ガス化で $69 \mathrm{kcal} / \mathrm{mol}$, $\mathrm{H}_{2} \mathrm{O}$ ガス化で $48.2 \mathrm{kcal} / \mathrm{mol}$ で, その差は $21 \mathrm{kcal} / \mathrm{mol}$ と 報告されている。他方, 常圧流動層での太平洋炭チャ

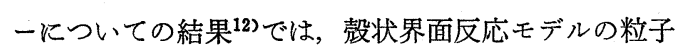
内拡散項に修正を加皃た速度式で解析された $\mathrm{E}$ は, $\mathrm{CO}_{2}$ ガス化で $44,1 \mathrm{kcal} / \mathrm{mol}, \mathrm{H}_{2} \mathrm{O}$ ガス化で $38.5 \mathrm{kcal} /$ $\mathrm{mol}$ で，その差は $5.6 \mathrm{kcal} / \mathrm{mol}$ である。これは本研究 の太平洋炭チャーについてもその差が小さいことと符 合する。

\subsection{2 チャ一粒子径の影響}

既述の実験に用いたチャ一粒径は平均粒径 $1.0 \mathrm{~mm} て ゙$

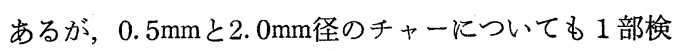
討した。1,400 では粒径の大きいものほどガス化速 度が低下寸る傾向がみられたが，1,000 C 以下では, 3 種の粒径によるガス化速度の違いは，ほとんどみら れず, $\mathrm{CO}_{2}$ ガス化と $\mathrm{H}_{2} \mathrm{O}$ ガス化のいずれの場合にお いても(11)式の粒径の次数 $\mathrm{n}$ は 0 とみなすことができ た。Kattaら ${ }^{27)}$ む $0.5 \mathrm{~mm}$ と0.9mm径のチャーの $\mathrm{H}_{2} \mathrm{O}$ ガス化を $982^{\circ} \mathrm{C}, 3$ 気圧で行い, ガス化速度にほとんど 差がみられなかったと報告している。 $1,000^{\circ} \mathrm{C}$ 付近以 下でのこれらの結果は, 体積基準反応モデル ${ }^{12688)}$ V基 づけば，いずれる粒子内拡散抵抗が無視小であること を示唆している。他方, 殼状界面反応モデル10)の界面 反応支配式を適用した速度解析結果 ${ }^{14) 15)}$ 子報告されて いるが，粒径の影響を詳しく論じた報告は見あたらな い。

\subsection{3 ガス化剈ガス分圧の影響}

$\mathrm{CO}_{2}$ ガス化速度に対する $\mathrm{CO}_{2}$ 分圧の次数 $\mathrm{m}$ への依

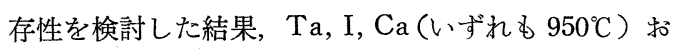
よびU $\left(1,000^{\circ} \mathrm{C}\right)$ そついては Table 2 と示したと括り $\mathrm{m}=0.45 \sim 0.54$ である。また I 亿対して温度を変劣た 場合の $\mathrm{m}$ は, $900^{\circ} \mathrm{C}$ で $0.58,950^{\circ} \mathrm{C}$ で $0.54,1,000^{\circ} \mathrm{C} て ゙$ 0.53であった。このように $1,000^{\circ} \mathrm{C}$ 以下での $\mathrm{CO}_{2}$ ガス 化に执いては，炭種や温度に関係なく，抢よそ $\mathrm{m}=1 / 2$ とみなしらる。Wenら ${ }^{11} は$, 活性炭, グラファイト， 石炭チャーなどの種々の炭素質の $\mathrm{CO}_{2}$ によるガス化 速度についての既往文献データを整理し， $\mathrm{m}$ の值が加 圧（15気圧）下では 0 に収束し, 常圧下では $\mathrm{CO}_{2}$ 分圧 が低い領域で 1 となり, 実験条件により $0 \leq \mathrm{m} \leq 1$ の間 で変化すると報告して和り，また $\mathrm{m}=1$ であるという 報告例8) ある。他方, Turkdoganら ${ }^{28229}$ は, $\mathrm{CO}_{2}$ ガ ス化でガス化剤中に共存する $\mathrm{CO}$ がガス化速度を抑制 する機構を詳しく検討し, $\mathrm{CO}$ 分圧が低く $\mathrm{CO}_{2}$-不活 
各種石炭チャーの二酸化炭素によるガス化の活性評価ならびにスチームによるガス化との比較(笠岡他) 343

性ガス系とみなせる場合と, $\mathrm{CO}_{2}-\mathrm{CO}$-不活性ガス系 では反応機構がまったく異なり, 前者の系では $\mathrm{m}=1 / 2$, 後者の系では $\mathrm{m}=1$ であると報告している。この $\mathrm{m}=$ $1 / 2$ は本研究の結果と一致し, ガス化剂 $\mathrm{CO}_{2}$ の解離吸着 により生成する表面酸化物 (Oads) C が気相 COへと ガス化する過程が律速であると考兄て導出される28)。 このことはまた, $\mathrm{CO}_{2}-\mathrm{N}_{2}$ 混合ガスによるガス化の本 研究では,チャ一粒子周りでのガスの淀みがなく, 押し 出し流れ系に近い微分反応器の条件をみたして拈り, 粒子表面の $\mathrm{CO}$ 分圧はきわめて低いと考えうることの 傍証であるといえる。

$\mathrm{H}_{2} \mathrm{O}$ ガス化の場合は Table 2 に示したと㧍り，Ta，

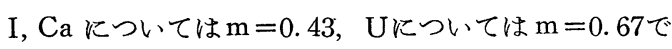
あった。同様の $\mathrm{H}_{2} \mathrm{O}$ ガス化に拈ける $\mathrm{m}$ にいて活性 炭(原料: 石炭)では $1^{13)}$, グラファイトでは $0.66^{30}$ と いう報告があり，また太平洋炭チャーについての国井

・古沢 ${ }^{31}$ の值 0.45 は本研究結果にきわめて近い。

さらに灰分が熔融する $1,300^{\circ} \mathrm{C}$ 付近の高温域で, Illinois \#6 炭チャーを例として，それぞれ $\mathrm{CO}_{2}$ 分圧 を0.125 0. 40 気圧扣よび $\mathrm{H}_{2} \mathrm{O}$ 分圧を $0.16 \sim 0.32$ 気圧 と変えてガス化を行った結果, mの值は, $\mathrm{CO}_{2}$ ガス化 で1. 03, $\mathrm{H}_{2} \mathrm{O}$ ガス化で0.84となり, いずれも $1,000^{\circ} \mathrm{C}$ 以下の化学反応支配の場合よりも大きくなり, 粒子内 外の物質移動抵抗が寄与しはじめていることを示唆し ている。

5.4 .4 速度解析結果の設計方程式としての適用

平均速度定数, (11)式と, 各種石炭チャーのガス化 速度相関式，(10)式とを用いて，任意の条件下に和け る速度曲線（ $\mathrm{f}$ 対 $\theta$ ）を推算する方法, すなわら設計 方程式としての本速度 モデル式の適用について述べ る。

$\mathrm{CO}_{2}$ ガス化を例としてつぎの速度表示式と Fig.6の 速度相関が成立する場合を考光る。

$$
\overline{\mathrm{k}}=\mathrm{k}_{\mathrm{o}} \mathrm{P}_{\mathrm{CO} 2}^{1 / 2} \exp (-\mathrm{E} / \mathrm{RT})
$$

つぎに $\mathrm{F}=\mathrm{f}$ であることに留意して $(10)$ 式を $\theta$ で微 分すると次式を得る。

$$
\mathrm{R}_{\mathrm{f}}=\mathrm{df} / \mathrm{d} \theta=\left(\mathrm{AB} / \theta_{\mathrm{f}=0.5}\right)\left(\theta / \theta_{\mathrm{f}=0.5}\right)^{\mathrm{B}-1}(1-\mathrm{f})
$$

同様に(5)式を $\theta$ で微分して(13)式と等置すると次 式が得られる。

$$
a_{\mathrm{STD}}=\mathrm{A}\left(\theta_{\mathrm{f}=0.5}\right)^{-\mathrm{B}}, \mathrm{b}_{\mathrm{STD}}=\mathrm{B}
$$

ここで添字 STD は，速度相関した特定の実験条件 （本例では, $950^{\circ} \mathrm{C}, \mathrm{P}_{\mathrm{CO} 2}=0.20$ 気圧）に拈淔で あることを示し，標準実験値と称することにする。

既述のように，すべてのチャーに対して $\mathrm{A}=0.693$
および $\mathrm{B}=1.216$ が一定であるとすると, これから推 定しようとする炭種に対する 標準実験に和ける $\theta_{\mathrm{f}=0.5}$ が既知であれば， asTD と bSTDは(14)式から算出でき るし，また(9)式と(14)式を用いて導かれる次式から $\overline{\mathrm{k}}_{\mathrm{STD}}$ を直接算出することもできる。

$$
\overline{\mathrm{k}}_{\mathrm{STD}}=\mathrm{A}^{1 / \mathrm{B}}\left(\mathrm{B} / \theta_{\mathrm{f}=0.5}\right)(\ln 2)^{(\mathrm{B}-1) / \mathrm{B}}
$$

ここで,ささらに活性化ェネルギーEが既知であれば, 推定すべき任意の条件 $\left(\mathrm{T}, \mathrm{P}_{\mathrm{CO} 2}\right)$ 下での速度定数 $\overline{\mathrm{k}}$ は, （16)式から算出され，したがって(9)式を書き換えた (17)式から a 值が推算できる。

$$
\begin{aligned}
& \overline{\mathrm{k}}=\overline{\mathrm{k}}_{\text {STD }}\left(\frac{\mathrm{P}}{\mathrm{P}_{\text {STD }}}\right)^{1 / 2} \exp \left[-\frac{\mathrm{E}}{\mathrm{R}}\left(\frac{1}{\mathrm{~T}}-\frac{1}{\mathrm{~T}_{\text {STD }}}\right)\right] \\
& \mathrm{a}=\left[\mathrm{B}^{-\mathrm{B}}(\ln 2)^{1-\mathrm{B}}\right] \cdot(\overline{\mathrm{k}})^{\mathrm{B}}=0.8533(\overline{\mathrm{k}})^{1.216}
\end{aligned}
$$

このようにaと Bが決定されると, $\mathrm{f}=1-\exp (-$ $\left.\mathrm{a} \theta^{\mathrm{B}}\right)$ から $\mathrm{f}$ 対 $\theta$ 曲線は容易に求めることができる。 このようとすべての炭種に対して共通のB值 (1.216) を用いる方法を第 1 法と呼ぶことにする。

Fig.9 は Callide 炭チャーについて, 本法により標 準実験 $\left(950^{\circ} \mathrm{C}, \mathrm{P}_{\mathrm{STD}}=0.2\right.$ 気圧）飞拈ける $\theta_{\mathrm{f}=0.5}=52$ $\min$ と, $\mathrm{E}=61.5 \mathrm{kcal} / \mathrm{mol}$ のみを用いて i ) $900^{\circ} \mathrm{C}$, $\mathrm{P}=0.4$ 気圧, ii ) $950^{\circ} \mathrm{C}, \mathrm{P}=0.1$ 気圧, iii） $950^{\circ} \mathrm{C}$, $\mathrm{P}=0.6$ 気圧の 3 つの場合に対して $\mathrm{f}$ 対 $\theta$ の関係を推 定し (図中の実線)，実測データ（ $\square, \bigcirc 、 \triangle)$ と比 較したものであり，両者はかなり良好に一致している。

さて，(14)式に打いて，bSTDを炭種に無関係に共通 のBの值を用いるのでなく，推定しようとする石炭チ ヤ一の標準実験に括ける值を直接用いればさらに推定 精度の向上が期待できると思われ，これを第 2 法と呼 ぶことにする。Fig.9 中の点線は，この方法による推 算結果である。しかし，他の Ta や I 炭チャーなどの 結果を考光合わすと, この方法は意外と精度が芳しく なく一般には第 1 法による方が精度がよいよらで, 論 理の簡易さからも第 1 法で十分である。なお，Fig. 9 の説明欄に示したよらに推算曲線のパラメータ（a， b)の值は, 実測データを直接解析して得られた ( $a_{e x p}$, $b_{\text {exp }}$ )の值と異なっているが，これは類似傾向の $\mathrm{f}$ 対 $\theta$ 曲線を与光るパラメーター $(\mathrm{a}, \mathrm{b})$ の組がいくつか 複数個存在することを示唆している。したがって，(5) 式のパラメーター $\mathrm{a}, \mathrm{b}$ の物理的な意義については検 討が必要である。後述するようにaはチャーの化学的

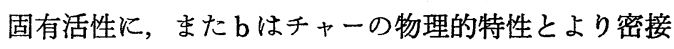
な関連性をるつパラメーターであると考觉られる。

5.5 チャーの表面積の経時変化 
非粘結性の太平洋炭と強粘結性の Illinois \#6 炭の チャーを選び，それぞれ $950^{\circ} \mathrm{C} て ゙ ~ \mathrm{CO}_{2}$ ガス化を行い， ガス化途中の 3 点でガス化を中断して $\mathrm{f}$ の異なるチャ 一を得, 未反応 $(\mathrm{f}=0)$ チャーをる含めて比表面積 $\mathrm{Sg}$ $\left(\mathrm{m}^{2} / \mathrm{g}\right)$ を測定し，ガス化の進行に伴らチャーの比表 面積と全表面積の変化で整理してそれぞれ Fig.10 と Fig.11とに示した。すなわち，Fig.10のよこ軸目盛の Yは，原料石炭重量を基準としたチャーの収率を，ま

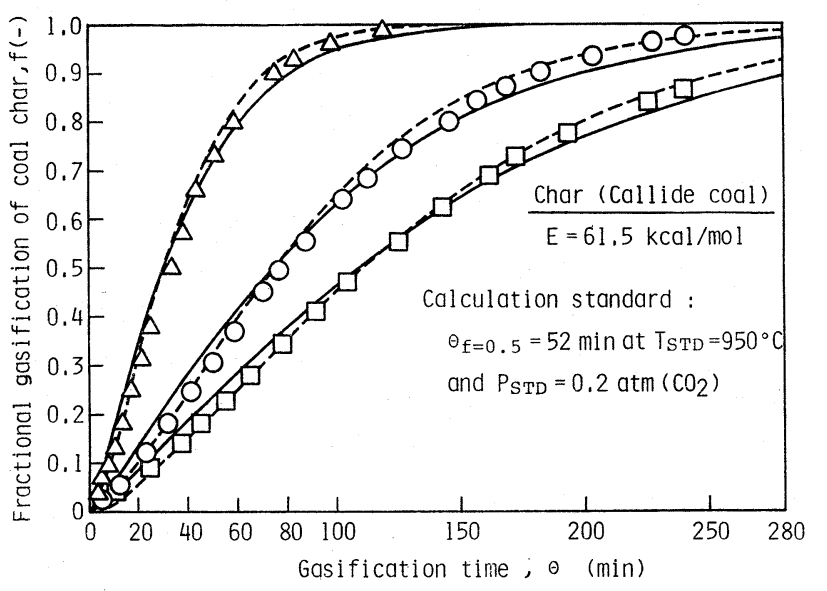

\begin{tabular}{|c|c|c|c|c|c|c|c|c|}
\hline \multicolumn{5}{|c|}{ Experimental } & \multicolumn{4}{|c|}{ Calculated } \\
\hline \multirow[b]{2}{*}{ Key } & \multirow{2}{*}{$\left(\begin{array}{c}\mathrm{T} \\
\left({ }^{\circ} \mathrm{C}\right)\end{array}\right.$} & \multirow{2}{*}{$\mid \begin{array}{l}\mathrm{P}_{\mathrm{CO}}^{2} \\
(\mathrm{~atm})\end{array}$} & \multirow{2}{*}{${ }^{\mathrm{a}} \exp$} & \multirow{2}{*}{$b_{\text {exp }}$} & \multicolumn{2}{|c|}{ Ist method } & \multicolumn{2}{|c|}{ 2nd method } \\
\hline & & & & & $a$ & $b$ & $a$ & $\mathrm{~b}$ \\
\hline$\square$ & 900 & 0.4 & $1.12 \times 10^{-3}$ & 1.366 & $2.34 \times 10^{-3}$ & & $8.57 \times 10^{-4}$ & \\
\hline 0 & 950 & 0.1 & $1.53 \times 10^{-3}$ & 1.404 & $3.74 \times 10^{-3}$ & 1.216 & $1.49 \times 10^{-3}$ & 1.424 \\
\hline$\Delta$ & 950 & 0.6 & $5.07 \times 10^{-3}$ & 1.412 & $1.11 \times 10^{-2}$ & (B) & $5.32 \times 10^{-3}$ & $\left(b_{S T D}\right)$ \\
\hline
\end{tabular}

Fig. 9 Examples of $f-\theta$ curves calculated by two methods for three different cases in $\mathrm{CO}_{2}$-gasification of coal char (Callide)

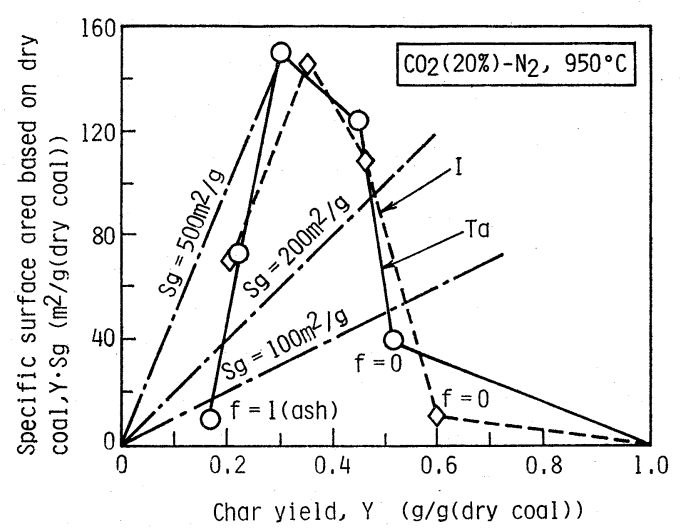

Fig. 10 Change of specific surface area of coal char during $\mathrm{CO}_{2}$-gasification
たたて軸目盛の YSg は原料石炭重量基準の表面積を 表して郝り, 原点を通る直線は等 $\mathrm{Sg}$ 線を示すことに なる ${ }^{32) 。 し た か ゙ っ て F i g .10 の ~} \mathrm{Y}=1$ の線上の点は原料 石炭に相当する。この例では, いずれの原料石炭の $\mathrm{Sg}$ もきわめて小さいが，熱分解後のチャー（図中の $\mathrm{f}=0$ 飞相当) では, いずれも $\mathrm{Sg}$ は $100 \mathrm{~m}^{2} / \mathrm{g}$ 以下ではある が，明らかに石炭よりも大きな細孔表面積をむってい ることがわかる。その後, ガス化が進むにつれて Sg は大きくなり, Yの 0.3 付近で最大 值を示したあと減少し, 既報33)のス チームによる石炭の直接賦活による 活性炭の製造でみられたと同様の細 孔の生成と消隇が起こっていること が示唆された。このことは, Fig.11に 示した初期試料チャー (150mg) の 全表面積の変化に㨟いてもまったく 同様である。

\section{6 修正体積反応モデルと Random Poreモデルの 比較}

ガス化速度を上述のような物理的 な細孔構造の変化の観点から表示し ようとする非触媒固・気反応モデル のひとつである Bhatiaら ${ }^{11)}$ の Random Pore モデルの化学反応支配 式は次式で表されている。

$$
\begin{gathered}
\mathrm{f}=1-\exp \left[-\mathrm{K}_{\mathrm{s}} \theta\right. \\
\left.\quad\left(1+\phi \mathrm{K}_{\mathrm{s}} \theta / 4\right)\right] \\
\phi=4 \pi \mathrm{L}_{\mathrm{o}}\left(1-\varepsilon_{\mathrm{o}}\right) / \mathrm{S}_{\mathrm{o}}{ }^{2}
\end{gathered}
$$

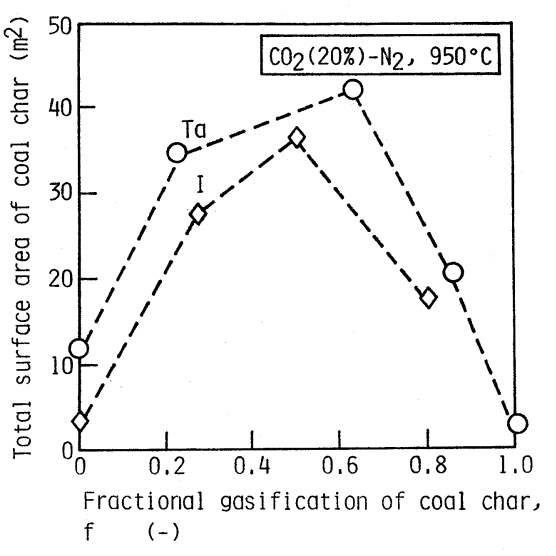

Fig. 11 Change of total surface area of initial coal char during $\mathrm{CO}_{2}$-gasification 
ここで， $\mathrm{L}_{\mathrm{o}}, \mathrm{S}_{\mathrm{o}}$ 护よび $\varepsilon_{\mathrm{o}}$ は，それぞれ初期試料チ ヤーの体積基準の 細孔の 重複長さ $\left(\mathrm{m} / \mathrm{m}^{3}\right)$, 表 面 積 $\left(\mathrm{m}^{2} / \mathrm{m}^{3}\right)$ および細孔容積 $\left(\mathrm{m}^{3} / \mathrm{m}^{3}\right.$,すなわち空孔率) であり，これらは，すべて理論上は，たとえば水銀ポ ロシメーターで測定される細孔容積分布曲線から求め られる。したがって山は構造パラメーターと呼ばれ， チャーの初期細孔構造によって定まる一定值である。

$\mathrm{K}_{\mathrm{S}}$ は細孔単位表面積当りの 化学反応速度定数比比例 しており，見かけ上は時間の逆数の単位をもつ化学反 応速度に関するパラメータである。

（18）式を $\theta$ で微分し，（4)式で定義した瞬間ガス化 速度 Ri を求めると, 次式が得られる。

$$
\mathrm{Ri}=\mathrm{K}_{\mathrm{s}}[1-\psi \ln (1-\mathrm{f})]^{1 / 2}
$$

これは本研究における修正体積反応モデル速度式, （5 式に基づく(7)式と比較でき，見かけ速度定数の $\mathrm{f}$ による変化を表す関係 $\mathrm{k}(\mathrm{f})$ の Random Pore モデ ルによる表示にほかならない。

そこで，(5)式を線型化して(6)式を得たと同様に （18)式を(21)式と(22)式のように2 通りに線型化し本 実験データに対し，KS と $\psi$ を一定とみなして，その 適合性を検討したが芳しくなかった。

$$
\begin{aligned}
& {[-\ln (1-\mathrm{f})] / \theta=\mathrm{K}_{\mathrm{S}}+\left(\psi \mathrm{K}_{\mathrm{S}^{2}} / 4\right) \theta} \\
& {[-\ln (1-\mathrm{f})] / \theta^{2}=\left(\phi \mathrm{K}_{\mathrm{S}}{ }^{2} / 4\right)+\mathrm{K}_{\mathrm{S}}(1 / \theta)}
\end{aligned}
$$

たとえば, Illinois \#6 炭チャーの $\mathrm{CO}_{2}$ ガス化で, 温度のみを変えた一連の実験結果（Fig.7）について，

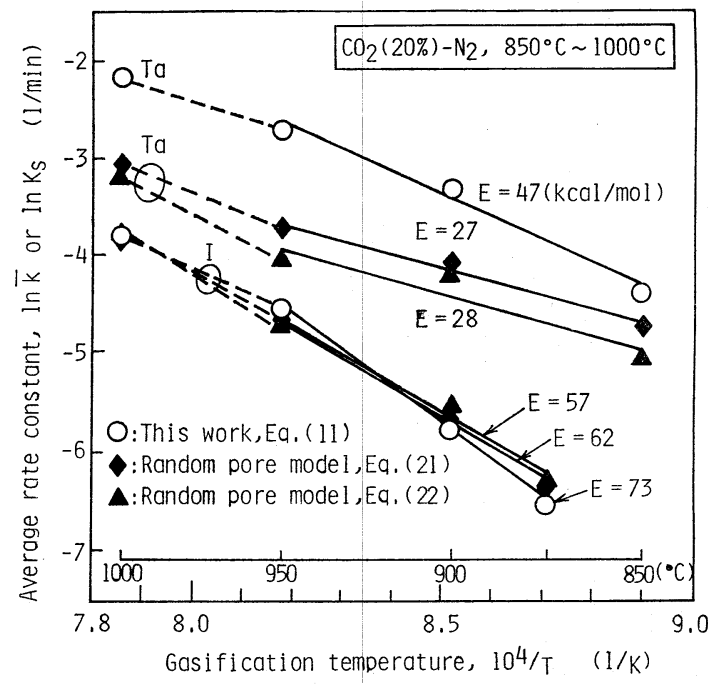

Fig. 12 Comparison of average rate constant

$(\overline{\mathbf{k}})$ based on modified volume model of this work with $\mathrm{ks}_{\mathrm{s}}$ based on random pore model, shown as a function of temperature
(21) 式と（22）式とから得られるパラメータの值を $\left(\mathrm{K}_{\mathrm{s}}, \psi\right)$ で表して比較すると，それぞれ $875^{\circ} \mathrm{C}$ では $\left(1.79 \times 10^{-3},-0.993\right)$ と $\left(1.84 \times 10^{-3},-1.48\right), 900$ ${ }^{\circ} \mathrm{C}$ では $\left(3.58 \times 10^{-3},-0.367\right)$ と $\left(3.87 \times 10^{-3},-1.08\right)$, $950^{\circ} \mathrm{C}$ では $\left(9.62 \times 10^{-3},+0.309\right)$ と $\left(8.78 \times 10^{-3},+\right.$ $1.23)$ また $1,000^{\circ} \mathrm{C}$ では $\left(2.36 \times 10^{-2},-0.074\right)$ と $\left(2.30 \times 10^{-2},+0.163\right)$ となり， $\mathrm{K}_{\mathrm{S}}$ の值は両式間では かなりよい一致が得られるものの, $\psi$ 值が一定とはな らず，しかも同一データに対しても(18)式の適用の仕 方によって得られる值が大きく異なり, かつ負の值が 得られるといら不合理な場合もみられた。

つぎに，太平洋炭チャーの $950^{\circ} \mathrm{C}$ に扣ける $\mathrm{CO}_{2}$ ガス 化で $\mathrm{CO}_{2}$ 分圧を变えたデータに対して, 同じょうに解 析を行った結果, 得られた $\left(\mathrm{K}_{\mathrm{S}}, \psi\right)$ 值は, 0.1 気圧で は $\left(1.87 \times 10^{-2}, 6.38\right)$ と $\left(1.46 \times 10^{-2}, 14.9\right), 0.2$ 気 圧では $\left(2.42 \times 10^{-2}, 9.79\right)$ と $\left(1.78 \times 10^{-2}, 24.4\right), 0.4$ 気圧では $\left(3.92 \times 10^{-2}, 5.48\right)$ と $\left(2.96 \times 10^{-2}, 14.3\right)$ お よび0.6気圧では $\left(5.18 \times 10^{-2}, 4.81\right)$ と $\left(4.36 \times 10^{-2}\right.$, 8. 89)であり, $\psi$ はすべて正の值として得られるるのの 適用式により $\psi$ は最小 4.81 から最大 24.4 まで拈よそ 5 倍の範囲で変化した。さらに23種の石炭チャーの $\mathrm{CO}_{2}$ ガス化データ（Fig.3，Fig.4) に対して(21)式と(22) 式を適用して解析した結果, Za, BW, K, B , S 特よび Ky の 6 種のチャーについては, $\psi$ がいずれの式によ る場合も負の值を示した。他方, チャー化条件は同じ ではないが1)，Fig.5に示した $\mathrm{H}_{2} \mathrm{O}$ ガス化データでは $\phi$ は負の值を示さなかったが, 適用式により $\phi$ 值は 1.5〜5倍も異なる場合がみられた。

さて, Random Pore モデルに和けるパラメータ $\mathrm{K}_{\mathrm{S}}$ は，本実験の $\overline{\mathrm{k}}$ と比較すると，Fig.12に代表例を示し たように絶対值はたがいに比較的近いといえるが，活 性化エネルギーは, $\overline{\mathrm{k}}$ による值 (Table 2) より常に小

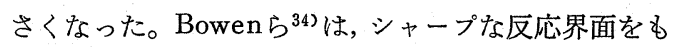
つ款状界面反応モデル10)と, ある厚みをるつ反応帯を 考皇たモデルと対比検討し, 反応速度を面積基準で表 した場合に得られる活性化エネルギーは, 体積基準で 表した場合の活性化エネルギーの1/2になることを理論 的に導出して拉り, 種々のモデル速度式に基づく活性 化エネルギーの比較については留意する必要がある。

Random Pore モデルで代表される構造反応モデル のように単位表面積当りのガス化速度は常に一定とし て，ガス化の過程を細孔表面積の生成消隇で記述する にはチャー表面でのガス化剤ガス分子との相互作用 ${ }^{21}$ 2228329) といらガス化現象は複雑すぎるといえよう。 (21)式や(22)式から求まる $\psi$ は, 上述のように物理的 
な意義を考慮すると不合理な点が多いが，しかし $\mathrm{f} の$ 0.5 付近のデータのみを用いた最小二乗法により機械 的に求まってくる $\mathrm{K}_{\mathrm{S}}$ と $\phi$ を用いて逆に(20)式から $\mathrm{f}$ 対 $\theta$ 曲線を推算すると, もとの実測データと比較的よ く近似することがわかった。そこで, $\mathrm{CO}_{2}$ ガス化データ (Fig.3)と $\mathrm{H}_{2} \mathrm{O}$ ガス化データ (Fig.5)のf $=0.2 \sim 0.8 の$ 範囲にある同一データを用いて, 改めて (6)式から b, (21)式と(22)式から $\psi$ を求めた。その結果, b と $\psi$ は, 原料石炭の燃料比や炭素含有率などとの相関性は見い だせなかった。ただ bと中の間には，つぎに示す線型 関係がかなりの精度で成立し, bがチャ一の物理構造 に関連した定数であることを示唆しているものと考光 られる。たと光ば(21)式から求まる $\phi$ の場合, $\mathrm{CO}_{2}$ ガ ス化 (Fig.3) に対しては,

$$
\begin{aligned}
\mathrm{b} & =1.14+0.257 \log \psi ; \mathrm{b}=0.722(\mathrm{~K}) \\
& \sim 1.499(\mathrm{Ma}), \phi=0.29(\mathrm{I}) \sim 12.0(\mathrm{Ma})
\end{aligned}
$$

$\mathrm{H}_{2} \mathrm{O}$ ガス化(Fig.5)に対しては,

$$
\begin{aligned}
\mathrm{b} & =1.16+0.290 \log \psi ; \mathrm{b}=1.123(\mathrm{Ta}) \\
& \sim 1.738(\mathrm{~S}), \phi=0.40(\mathrm{Ta}) \sim 95.2(\mathrm{~S})(24)
\end{aligned}
$$

$\mathrm{b}$ の炭種による变化の範囲は, $\psi$ に比べて大变狭く, したがって，既述のように炭種に無関係に一定とみな す，非常に簡便な取り扱いのできることがうなづかれ る。

\section{6. 結 言}

燃料比が 1 から 8 の範囲にある国内外産の 23 種の石 炭から同一条件で調製したチャーについて, 常圧下, $800 \sim 1,400^{\circ} \mathrm{C}$ で $\mathrm{CO}_{2}(10 \sim 60 \%)-\mathrm{N}_{2}$ 混合ガスによる ガス化を行い, ガス化速度と生成ガス組成の経時変化 を測定した。ガス化速度は，(5)式の修正体積反応モ デル速度式により解析し, 定量的な活性評価を行い, また $\mathrm{H}_{2} \mathrm{O}(16 \sim 41 \%)-\mathrm{N}_{2}$ 混合ガスによるガス化も行 って, $\mathrm{CO}_{2}$ と $\mathrm{H}_{2} \mathrm{O}$ によるガス化の速度論的な対比・ 検討を行った。得られた括もな知見と結果は，つぎの と括りである。

（1）代表速度定数 $\bar{k} ， （ 8)$ 式で評価されるチャーの 活性と原料石炭の燃料比の 関係は, $\mathrm{CO}_{2}(20 \%)-\mathrm{N}_{2}$ (950 ${ }^{\circ} \mathrm{C}$; Fig.4), $\mathrm{H}_{2} \mathrm{O}(24 \%)-\mathrm{N}_{2}\left(850^{\circ} \mathrm{C}\right.$; Fig.5) 括 よび $\mathrm{O}_{2}(10 \%)-\mathrm{N}_{2}\left(900^{\circ} \mathrm{C}\right)^{1)}$ の 3 つ場合とも, 燃料比 が 1 から 3 付近まで急激に低下して，3 付近で最小值 を示し, 3 付近以上の傾きは $\mathrm{CO}_{2}, \mathrm{H}_{2} \mathrm{O}, \mathrm{O}_{2}$ とガス化 剤ガスの酸化力の順に緩やかになるものの, たがいに 類似した活性傾向を示す。

(2) ガス化率 $\mathrm{f}$ 対ガス化時間 $\theta$ の曲線は, $\mathrm{f}=0.5$ K 達するに要する時間 $\theta_{\mathrm{f}=0.5}$ で無次元化した時間 $\theta / \theta_{\mathrm{f}=0.5}$
を採用すると，いずれのガス化に対してる，それぞれ (5)式と, 同型式(10)で表される1本の曲線で相関さ れる (Fig.6)。

以下は, 太平洋炭 ( $\mathrm{Ta}$; 褐炭), Callide 炭 ( $\mathrm{Ca}$; 非粘結性瀝青炭), Illinois \#6 炭 ( I ; 粘結性瀝青炭) 扣よび魚貫炭 (U；無煙炭) の 4 種のチャーを代表に 選び検討した結果である。

(3) $\mathrm{CO}_{2}$ 㧊よび $\mathrm{H}_{2} \mathrm{O}$ によるいずれの ガス化でも $1,000^{\circ} \mathrm{C}$ 以下では化学反応支配であり, 炭種による活 性 $\overline{\mathrm{k}}$ の序列や違いの程度は灰分の熔融がみられる1300 $\sim 1400^{\circ} \mathrm{C}$ の高温域までも変化しない(Fig.7，8)。

(4) 化学反応支配域に和けるガス化速度のガス化剤 ガス分圧の次数依存性は, $\mathrm{CO}_{2}$ ガス化では, 炭種には注 とんぞ関係なく 0.5 次, $\mathrm{H}_{2} \mathrm{O}$ ガス化では, Ta, Ca, I と 対して0.43次, Uに対して0.67次である。

（5）ガス化条件と $\overline{\mathrm{k}}$ の関係式, (11)式と, ガス化速 度相関式，(10)式を組み合わせて, 簡単なデータから $\mathrm{f}$ 対 $\theta$ 曲線を精度よく推定できる。

（6）ガス化過程をチャ一の表面積の変化で記述する Random Pore モデルの 化学反応支配式，(18）式と 本研究における(5)式との対比を理論的かつ実験的に

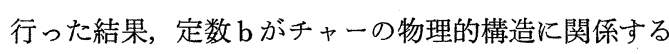
パラメータであると考兄られる。しかし(18)式のデー タへの適合を試みた結果は, チャーの初期細孔構造で 定まるとされる定数 $\phi,(19)$ 式がガス化途中で一定と はならず，かつ負になるなどの不合理が生じる場合が 多くみられる。

チャーのガス化速度・活性を強、支配するのは, 含 有鉱物の成分や量, 細孔構造などの化学的・物理的因 子にもまして，チャ一表面でのガス化肪ガス分子との 相互作用，すなわち表面反応を支配するチャー表面の 化学的性質であろうと示唆された。したがって, ガス 化剂ガス組成が本研究のように $\mathrm{CO}_{2}$ や $\mathrm{H}_{2} \mathrm{O}$ のみなら ず, $\mathrm{CO}, \mathrm{H}_{2}, \mathrm{CH}_{4}$ などの還元性ガスを共存する場合の 活性評価は, さらに複雑となり ${ }^{5211}$, 別途に検討を進 めている。

本研究は, 文部省科学研究費 (エネルギー特別研究) によった。

\section{文献}

1) 笠岡成光, 阪田祐作, 柏野 茂, 益岡康夫, 化学 工学論文集, 8,174 (1982)

2) Bhatia, S. K. and Perlmutter, D. D., AIChE Journal, 26, 379 (1980)

3) Rao, C. P. and Gluskoter, H. J., Illinois State Geol. Survay Circ., 476 (1973) 
各種石炭チャーの二酸化炭素によるガス化の活性評価ならびにスチームによるガス化との比較(笠岡他) 347

4）笠岡成光, 阪田祐作, 益岡康夫, 化学工学協会第 47年会発表要旨集, p.20（1982）

5）笠岡成光，阪田祐作，山下弘文，西野 徹，燃協 誌, 58, 373 (1979). Intern. Chem. Eng., 21, 419 (1981)

6）笠岡成光，阪田祐作，化学工学，30，50（1966）

7) Johnson, J.L., "Coal Gasification", ACS Adv. in Chem. Ser., No.131, p. 145 (1974)

8) Wen, C, Y. and Wu, N. T., AIChE Journal, 22, 1012 (1976)

9）笠岡成光, 阪田祐作, 柏野 茂, 化学工学論文集, 8, 51 (1982)

10）矢木 栄, 国井大蔵, 工化誌, 56, 131 (1953)

11) Dutta, S., Wen, C. Y. and Belt, R. J., Ind. Eng. Chem., Proc. Des. Dev., 16, 20 (1977)

12）武田詔平, 河端淳一, 弓山 翠, 田崎米四郎, 本 間専治，森 滋勝，燃協誌，59，64（1980）

13）金 革, 木村彰一, 東稔節治, 大竹伝雄, 石油誌, 24, 344 (1981)

14) Guzman, G. L. and Wolf, E. E., Ind. Eng. Chem., Proc. Des. Dev., 21, 25 (1982)

15) Schmal, M., Monteiro, J.L. F. and Castellan, J. L., Ind. Eng. Chem., Proc. Des. Dev., 21, 256 (1982)

16) Tomita, A., Mahajan, O.P. and Walker, P. L. Jr., Fuel, 56, 137 (1977)

17) Otto, K., Bartosiewicz, L. and Shelef, M., Fuel, 58, 85 (1979)

18) Rai, C. and Tran, D. Q., Fuel, 58,603(1979)

19) Suuberg, E. M., Peters, W. A. and Howard J. B., Ind. Eng. Chem., Proc. Des. Dev., 17, 37 (1978)

20）中村 尊, 原田哲也, 和井内 徹, 日化, 1870 (1980)
21）笠岡成光, 阪田祐作, 栢野，茂, 日化，583 (1983)

22) Walker, P. L. Jr., Shelef, M. and Anderson, R. A., Chemistry and Physics of Carbon, 4, 287 (1968)

23) Mahajan, O.P., Yarzab, R. and Walker, P. L. Jr., Fuel, 57, 643 (1978)

24）笠岡成光, 阪田祐作，柏野 茂，益岡康夫，第48 回触媒討論会(A)予稿集, p.240（1981）

25) Tomita, A., Mahajan, O.P. and Walker, P.L. Jr., Prepr., Div. Fuel Chem., ACS, 22, (1), 4 (1979)

26）笠岡成光，笹岡英司，尾崎篤志，燃協誌，61, 1086 (1982)

27) Katta, S. and Kealrns, D. L., Ind. Eng. Chem. Fundam., 20, 6 (1981)

28) Turkdogan, E. T. and Vinters, J. V., Carbon, 7, 101 (1969)

29) Turkdogan, E. T. and Vinters, J. V., ibid., 8, 39 (1970)

30) Pilcher, J.M., Walker, P.L. Jr, and Wright, C. C., Ind. Eng. Chem., 47, 1742 (1955)

31）松井 功, 古沢健彦, 国井大蔵, 化学工学協会第 15回秋季大会発表要旨集, p.475（1981）

32）笠岡成光, 阪田祐作, 三村篤幸, 山戸秀夫, 日化, 1631 (1976), Intern. Chem. Eng., 20, 446 (1980)

33）笠岡成光，阪田祐作，梅野誠，足立芳郎，森下仡 志, 日化, 1569 (1979)

34) Bowen, J.H. and Cheng, C. K., Chem. Eng. Sci., 24, 1829 (1969) 


\title{
Kinetic Evaluation of Reactivity in Carbon Dioxide- Gasification of Various Coal Chars, and Comparison with Steam-Gasification
}

\author{
Shigeaki KASAOKA, Yusaku SAKATA and Chuliang TONG \\ (School of Engineering, Okayama University)
}

SYNOPSIS : - The 23 kinds of coals, whose fuel ratio ranged 1 to 8 , were devolatilized under the same condition, and the resulting chars were gasified with $\mathrm{CO}_{2}(10 \sim$ $60 \%)-\mathrm{N}_{2}$ mixture under an atmospheric pressure at $800^{\circ} \mathrm{C} \sim 1,400^{\circ} \mathrm{C}$ to determine the gasification rate gravimetrically and the outlet gas composition.

The gasification reactivities of chars were analyzed quantitatively by applying our rate expression, $\mathrm{f}=1-\exp \left(-\mathrm{a} \theta^{\mathrm{b}}\right)$, which was regarded as a modified volume reaction model, and compared with the reactivity of gasification with $\mathrm{H}_{2} \mathrm{O}(16-41 \%)-\mathrm{N}_{2}$ mixture. Also, a limitation of the rate expression based on random pore model was discussed experimentally.

Main results obatined were as follows :

(1) The char reactivities evaluated by average rate constant $(\overline{\mathrm{k}})$ for the gasification with $\mathrm{CO}_{2}\left(20 \%, 950^{\circ} \mathrm{C}\right.$; Fig. 4$), \mathrm{H}_{2} \mathrm{O}\left(24 \%, 850^{\circ} \mathrm{C}\right.$; Fig. 5$)$ and $\mathrm{O}_{2}\left(10 \%, 900^{\circ} \mathrm{C}\right)$ showed almost the same dependency on the fuel ratio (FR) of parent coals; i.e. the reactivity decreased to minimum at about 3 of $\mathrm{FR}$, and their changes in the range of $\mathrm{FR}<3$ were much steeper than those of FR>3.

(2) By adopting a reduced time $\tau=\theta / \theta_{\mathrm{f}}=0.5$, the 23 rate-curves shown by fractional gasification of char $f$ vs. gasifying time $\theta$ were unified to a curve which was also expressed by equation, $\mathrm{F}=1-\exp \left(-\mathrm{A} \tau^{\mathrm{B}}\right)$, the same form with prior equation, $\theta_{\mathrm{f}}=0.5$ is the time to be at $\mathrm{f}=0.5$.

Followings were the results from discussions on four representative coal chars, Taiheiyo ( $\mathrm{Ta}$ : brown coal), Callide(Ca:non-caking bituminous), Illinois \#6 (I:strongly caking bituminous) and Uonuki (U : anthracite).

(3) The rates of gasification with $\mathrm{CO}_{2}$ and $\mathrm{H}_{2} \mathrm{O}$ were chemically controlled below $1,000^{\circ} \mathrm{C}$; and no change in the order of gasification reactivity of char were detected up to the high temperature range of $1,300^{\circ} \mathrm{C} \sim 1,400^{\circ} \mathrm{C}$, where the ash in most char was found to be melted.

(4) The proportionality of gasification rate to concentration of gasifying gas was determined in chemically-controlled region: the gasification with $\mathrm{CO}_{2}$ showed power of 0.5 independently of coal, but the gasification with $\mathrm{H}_{2} \mathrm{O}$ had power of 0.43 for chars of $\mathrm{Ta}, \mathrm{Ca}$ and $\mathrm{I}$, and 0.67 for char of $\mathrm{U}$.

(5) A simple method was proposed to estimate $f$ vs. $\theta$ relation for the reactor design based on this modified volume reaction model (Fig.11).

(6) The random pore model equation in chemically-controlled region was tried to fit in the rate data of this work, but the pore structure parameter $\psi$ and the rate parameter $\mathrm{K}_{\mathrm{s}}$, which were determined as the original properties of sample char, were found not to be constant through gasification.

(7) As a conclusion, it was strongly suggested that the chemical properties of char surface, on which gasifying molecules had an interaction to gasify carbonaceous material, were much more predominant factors to rule the gasification reactivity than the structure/ surfacearea of pore and component/contents of mineral matters in char.

Therefore the evaluation of gasification reactivity in an atmosphere composed of not only $\mathrm{CO}_{2}$ or $\mathrm{H}_{2} \mathrm{O}$, but also the reductive gases such as $\mathrm{CO}, \mathrm{H}_{2}$ and $\mathrm{CH}_{4}$ may be more complicated; and an experimental study on this line is now in progress.

\section{Key Words}

Fuel ratio, Gasification of coal chars, Rate expression of coal char-gasification, Volume reaction model, Random pore model, Reactivity of coal char 